\title{
Comparason between Ras Baroud and Abu Hadeida Granites, Northern Eastern Desert, Egypt. To Determine the More Evolved One
}

\author{
Mohamed Abd El Monsif \\ Nuclear Materials Authority. P.O. Box 530, El-Maadi, Cairo, Egypt
}

*Corresponding Author: Mohamed Abd El Monsif, Nuclear Materials Authority. P.O. Box 530, El-

Maadi, Cairo, Egypt, drmonsifzaky@hotmail.com

\begin{abstract}
Abu Hadeida are more affected by tectonism than Ras Baroud, resulting many alteration zones that contain a lot of important mineral assosciations, especially radioactive ones. Petrographically, it was noticed the absence or scarcity of the plagioclase in Abu Hadeida granite with respect to Ras Baroud. Field, petrographic and mineralogical studies indicate that the main mineral associations occur in altered microgranite rocks in comparison to Ras Baroud which are incorporated with pegmatites. The mineral associations in Abu Hadeida granite are represented by $\mathrm{Nb}$-Ta minerals (columbite, samarskite), accessory minerals (fluorite and zircon), in addition to secondary uranium and lead minerals (uranophane and curite), while in Ras Baroud they are characterized by $\mathrm{Nb}$-Ta minerals (samarskite and columbite), tin mineral (cassiterite) and accessory minerals (fluorite, zircon and rutile). The higher radioelements content of Abu Hadeida granitic rocks in comparison with Ras Baroud is mainly attributed to the abundance of radioactive minerals in Abu Hadeida granitic relative to Ras Baroud. Chemically, in Abu Hadeida granite the trace elements have higher concentrations than Ras Baroud except barium and cupper, the higher contents in Ras Baroud may be attributed to the presence of the plagioclase mineral granite and its rarity or disappearance in Abu Hadeida granite and the copper contents could be related to sulphides. It also confirms that Abu Hadeida granite is one of the most promising types in Egypt, containing high concentrations of uranium and thorium, which leads us to confirm that this granite emanated from a magma rich in minerals, including radioactive minerals that may be sourced from the magma molten or by the following processes, including hydrothermal solutions that worked on precipitation those minerals in the form of easy to extract. Geochemically and radiometrically, it is indicated that the radioactive mineralization in Abu Hadeida is mainly connected to magmatic processes, in contrast to Ras Baroud, which is mainly related to late hydrothermal processes. Uranium shows migration-out in Abu Hadeida granites mainly to the weak planes of its associating microgranite, while it illustrates migration-in in Ras Baroud.
\end{abstract}

Keywords: Uranophane and Curite, Abu Hadeida granite, Ras Baroud, Egypt.

\section{INTRODUCTION}

The younger granites constitute about 16.2\% of the basement in the Eastern Desert (Stern, 1979) and concentrated in its northern part. They form small rounded to ovoid masses of magmatic origin with sharp intrusive contacts (El Ramly,1972) and their ages range between 594 and 568m.y.The younger granites were emplaced during the post tectonic episode in Egypt, contemporaneous with the PanAfrican thermal events. Their age ranges from 620 to 530Ma (Rogers and Greenberg,1983).

Most of radioactive occurrences in the basement rocks of Egypt are in the granites and associated pegmatites. The high radioactivity level of these rocks is attributed to the presence of accessory minerals e.g. zircon, monazite, thorite, uranothorite and allanite (Schürmann, 1966).

$\mathrm{Nb}$-Ta mineralization in the Eastern Desert of Egypt has a direct relationship with the granites (Sabet and Tsogoev, 1973). Such a type of granite is commonly termed "apogranite" and it is believed to be a special type of metasomatic granitoids (Beus, 1982).

Abu Hadieda area is located in the Northern Eastern Desert of Egypt at about $20 \mathrm{~km}$ westward from Safaga City at the Red Sea coast. The area can be easily accessed via a newly established part of Qena-Safaga asphaltic road, along W. Baroud Al Abyad, which runs directly to the north of the area. The region has an area of $26 \mathrm{~km}^{2}$ bounded by latitudes $26^{\circ} 42^{\prime} 54^{\prime \prime}$ and $26^{\circ} 45^{\prime} 36^{\prime \prime} \mathrm{N}$ and longitudes $33^{\circ}$ $44^{\prime} 06^{\prime \prime}$ and $33^{\circ} 47^{\prime} 42^{\prime \prime E}$ (Fig.1). 
Comparason between Ras Baroud and Abu Hadeida Granites, Northern Eastern Desert, Egypt. To Determine the More Evolved One

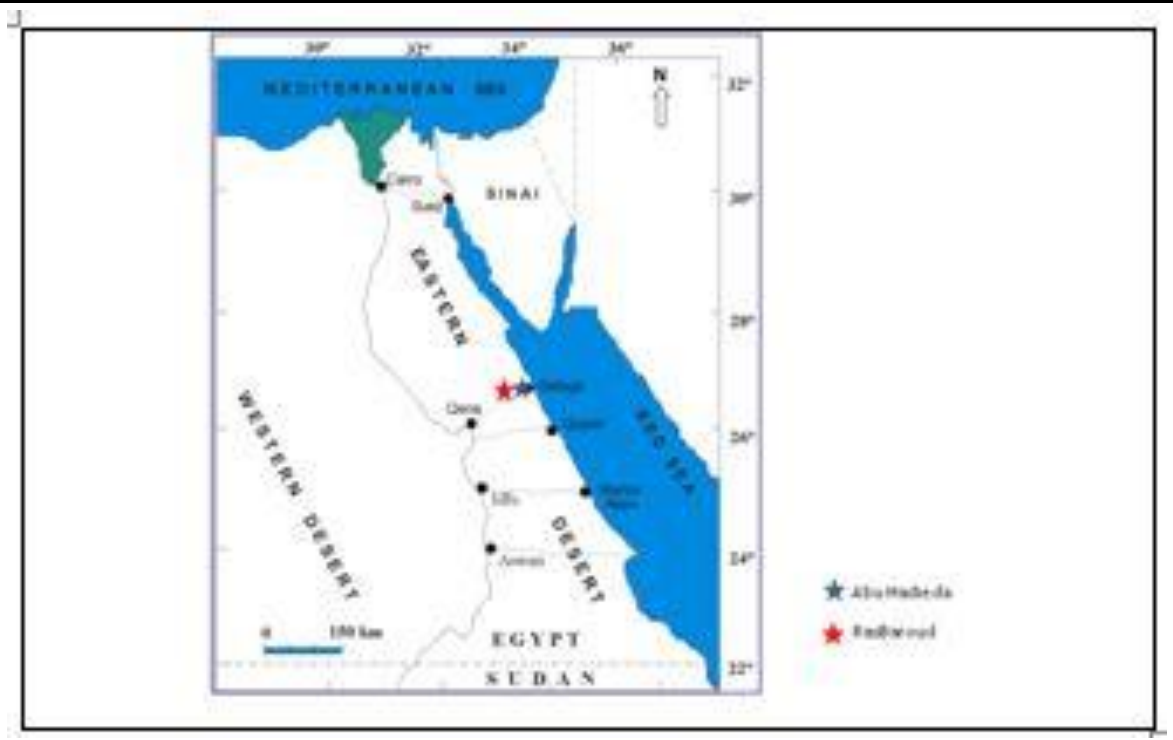

Fig.1. Location Map of the studied areas Northern Eastern Desert, Egypt.

The area is characterized by its rugged topography and high relief. It is intersected by wadi Ras Abda and wadi Abu Hadieda and moreover it is limited to the North and to the South by wadi Ras Baroud and wadi Um Taghir respectively (Fig.2).

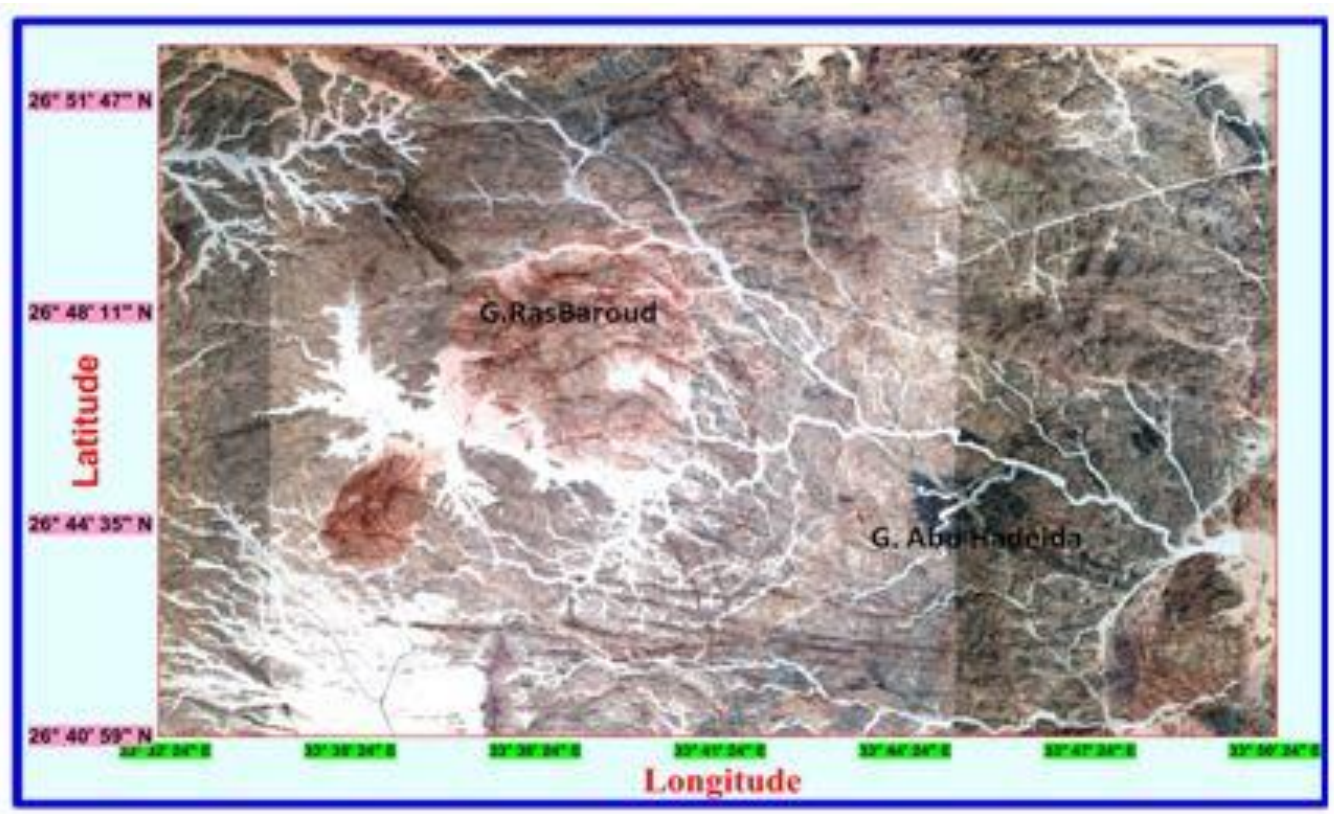

Fig.2. Landsat image show Ras Baroud and Abu Hadeida areas, Northern Eastern Desert, Egypt

There are few detailed investigations combined with radiometric and mineralogical studies carried out on the South Abu Hadeida area(e.g. Omran, 2005 \& El Hadary et al, 2013 and Omran,2014).High radioactivity levels were discovered for the first time in Abu Hadeida area by (Omran,2005). The high radioactivity of the area is related to poly-mineralized microgranite offshoots invaded the older granitoid rocks( Omran 2014).

On the other hand, Ras Baroud area is located in the Central Eastern Desert of Egypt and bounded by latitudes $26^{\circ} 433^{\prime} 48^{\prime \prime}$ and $26^{\circ} 48^{\prime} 36^{\prime \prime} \mathrm{N}$ and longitudes $33^{\circ} 35^{\prime} 24^{\prime \prime}$ and $33^{\circ} 45^{\prime} \mathrm{E}$, directly to the north of Qena Safaga asphaltic road at 35Km from Safaga city (see fig.1) The geology of the area has been studied by several authors (e.g. Mahdy et al., 1991, Sayyah et al.,1993, Omar 1995,Zalata et al., 1996 and Surour et al.,2004).

This study aims to compare between Abu Hadeida and Ras Baroud granites, radimetrically, geochemically, mineralogically and identify the extent of similarity between them, as well as knowing which locality is more developed. 


\section{Methodology}

All microscopic, chemical and mineralogical studies were carried out in the labs of Nuclear Materials Authority. The rocks examined microscopically by polarized light microscope attached with digital camera. Trace elements were analyzed by XRF technique. These samples crushed to different size ranging from $1 \mathrm{~mm}$ to $0.63 \mathrm{~mm}$, washed by $\mathrm{H}_{2} \mathrm{O}_{2}$, and $\mathrm{HCl}$, then drayed. A representative sample of about $60 \mathrm{gm}$ from each sample was separated by heavy liquid bromo form $2.88 \mathrm{gr} / \mathrm{cm}^{3}$ and studied by using binocular stereomicroscope. Semi quantitative EDX chemical analyses were also carried out using a Phillips XL-30 Environmental Scanning Electron Microscope (ESEM).

\section{GEOLOGICAL SETTING}

Abu Hadeida area occupied with rock unites arranged from the oldest to the youngest as; older granites, younger gabbros, younger granites and microgranitic offshoots in addition to basic and acidic dikes (Fig.3).

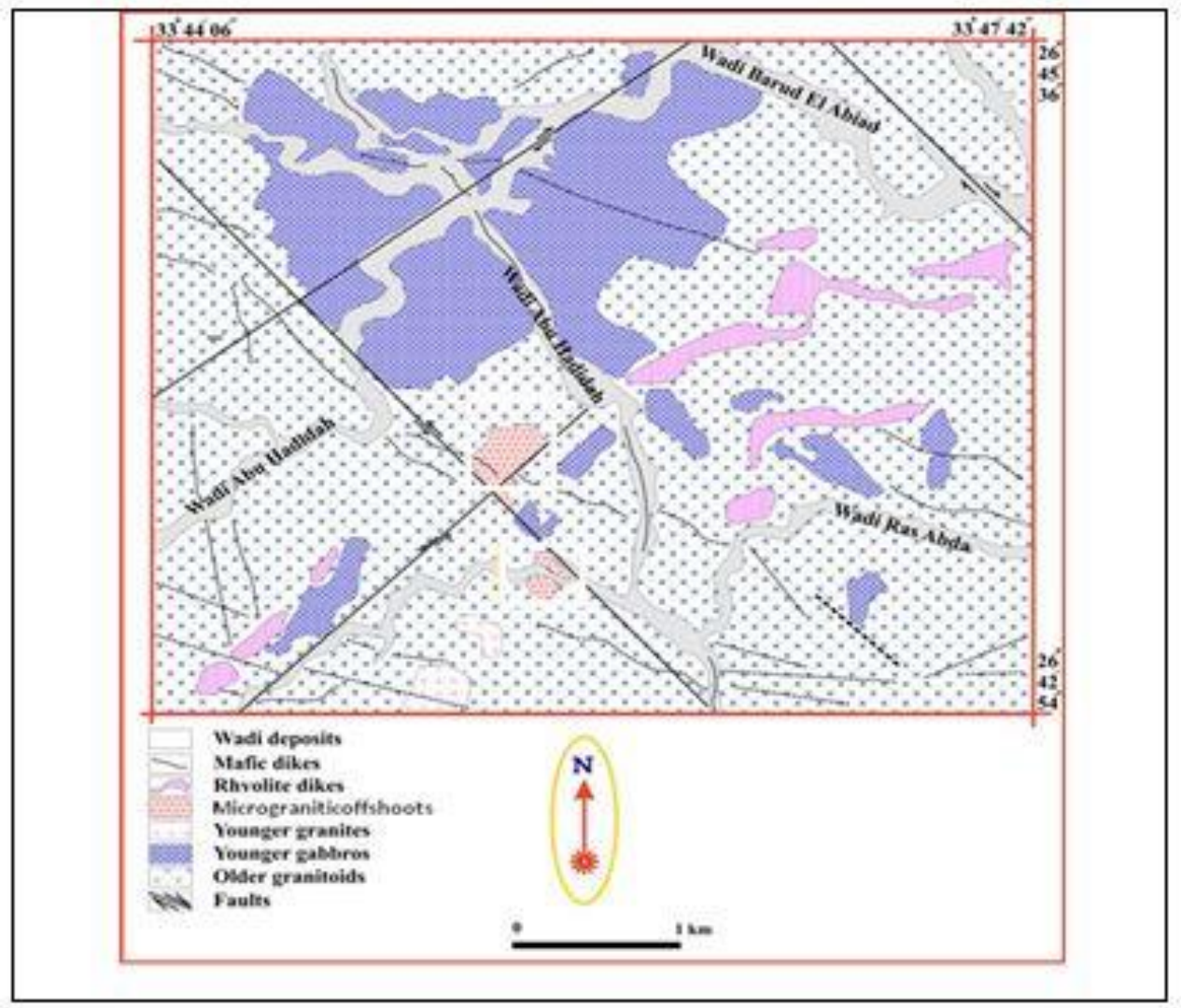

Fig.3. Geological map of Abu Hadeida area (Modified after Omran, 2014).

The younger granites and microgranite offshoots are found in different size and shapes intruding older granitoids (Fig.4) and the younger gabbros(Fig.5).The microgranite offshoots occur as vertical walls and/or elongated elliptical-shaped bodies, with outcrop dimensions range from few meters to hundred meters in length and from less than a meter up to tens of meters in width. On the other hand, this offshoot is fine to medium grain, hard, compact and shows various degrees of colors including red, pink, reddish pink, whitish pink, greyish pink and faint yellowish pink colors due to the effect of hydrothermal solutions. Younger granites have the highest radioactivity level in the area including zones of anomalous mineralization especially in microgranite offshoots bodies.

Many hydrothermal alteration processes such as hematitization, silicification, kaolinization, episyenitization (Fig.6), chloritization and manganese dendrites are affecting the rocks with different degrees of intensity. The hematitization and silicification are the most common alteration features. Hematitization always exists in the fractured zones accompanied with visible uranium mineralizations (Fig.7), due to the high ability of iron oxides to adsorb uranium from its bearing solutions or may be resulted the prevailing oxidation processes (Hussein et al.1965 and El Feky,2011). Pegmatite body is unzoned type and mostly combined with the fractures and joints. 


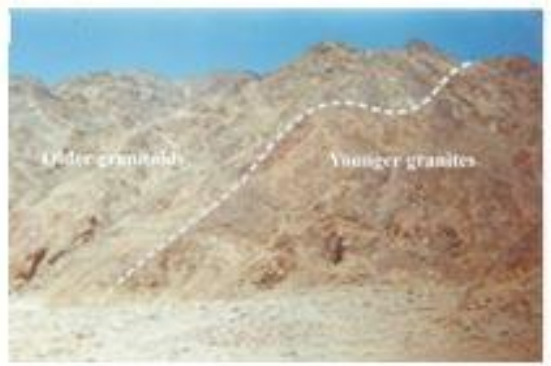

Fig4. Younger granites intruding the older granitoids

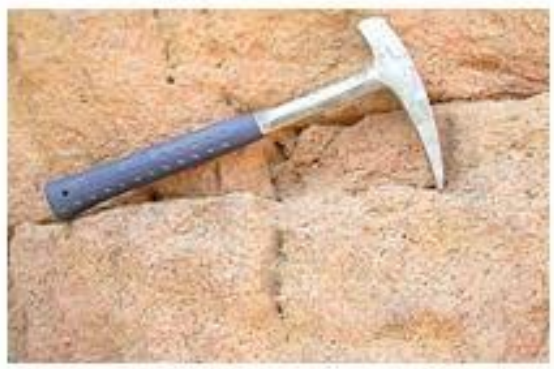

Fig6. Episyenitization in microgranitic

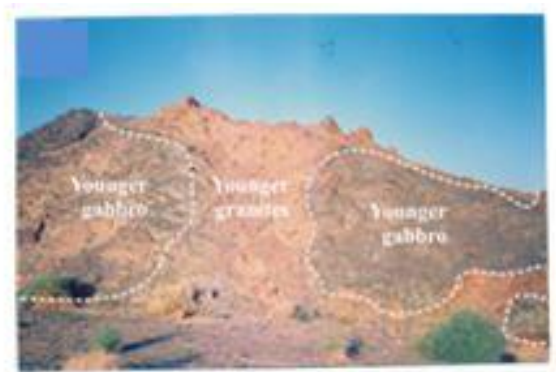

Fig5. Younger granites intruding the younger gabbr

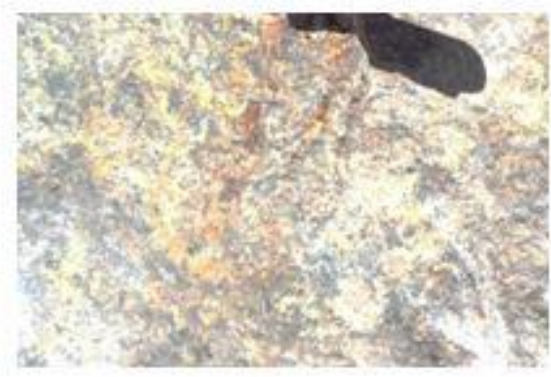

Fig7. uranium-mineralization with iron oxides

On the other hand, there are different morphological features in Ras Baroud area range from low to moderate except younger granite which is relatively high, with prominent peaks up to $1446 \mathrm{~m}$ above sea level. The rock unites in Ras Baroud area are arranged from the oldest to the youngest into older granites, younger granites and dikes (Fig.8).

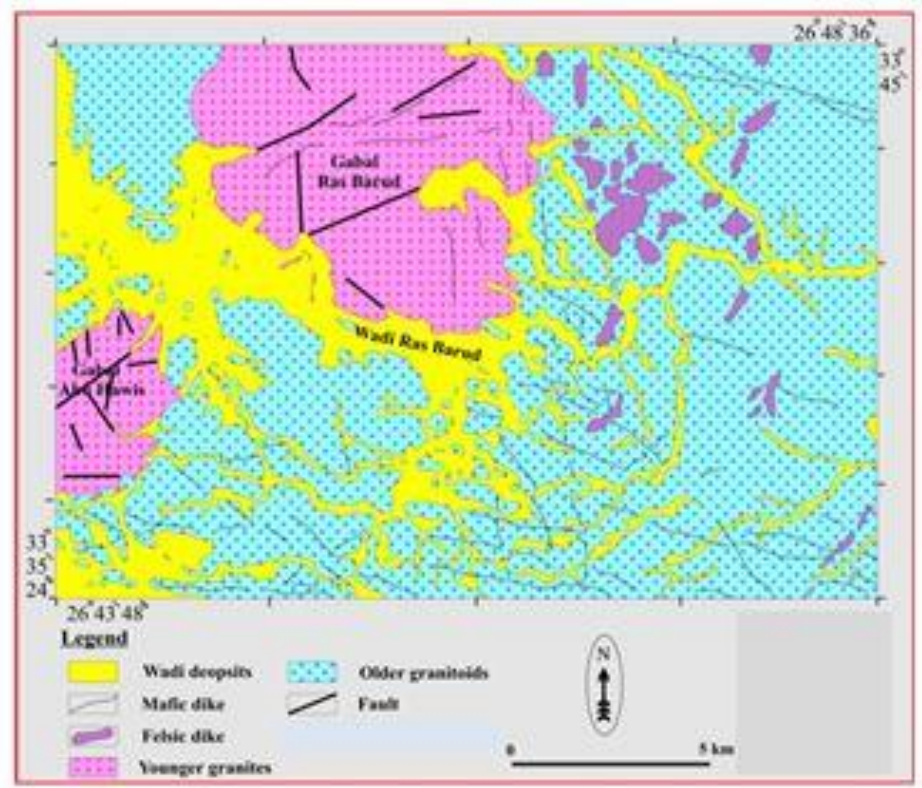

Fig8. Geological map of Ras Baroud area (Modified after El Azb,et.al.,2014).

Ras Baroud younger granite is syenogranite and exposed as huge semirounded isolated pluton with an area of $40 \mathrm{Km}^{2}$ (Fig.9). It is nearly trending in the N-S direction. This granite is medium to coarse grained and pink to reddish pink in color. Ras Baroud granite is strongly jointed, faulted and intruded by numerous dikes with different composition range from acidic to basic in different directions (Fig.10). This granite intrudes all the surrounding country rocks and send several offshoots into them. Also, it contains xenoliths of different shapes and sizes from the surrounding older rocks. These xenoliths show different stages of digestion depending on their size and composition. The intensity and size of these xenoliths increase gradually toward the contact with the country rocks. The contact between this granite and its surrounding rocks is rather sharp and well defined. The younger granite is strongly weathered, showing exfoliation, bouldery and cavernous weathering. 
Several pegmatite bodies are encountered at the peripheral parts of the younger granite with some alteration features such as hematization, illitization and fluoritization. Most of mineralizations are related to the pegmatite bodies which located at the Northern and Southern peripheries of the younger granite (Fig.11).

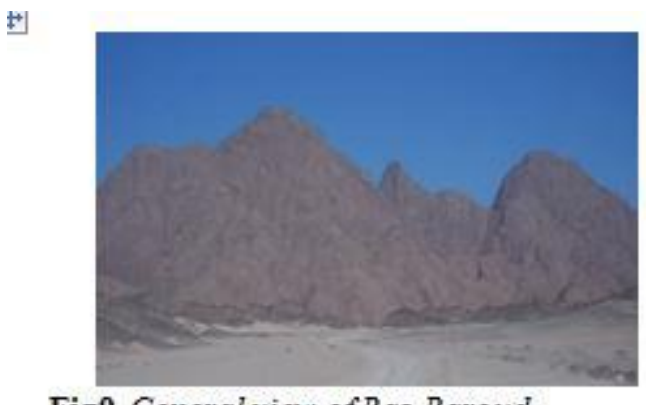

Fig9. General view of Ras Baroud younger granites.

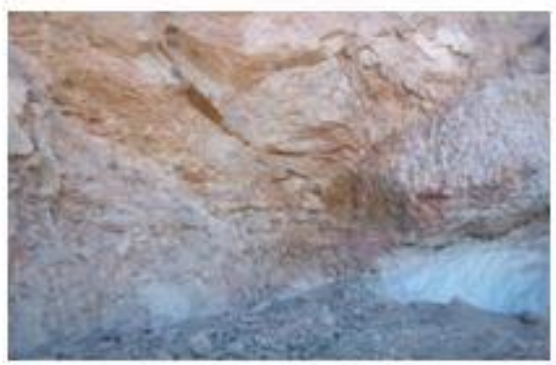

Figll. Pegmatite body at the periphery of Ras Baroud younger granites.

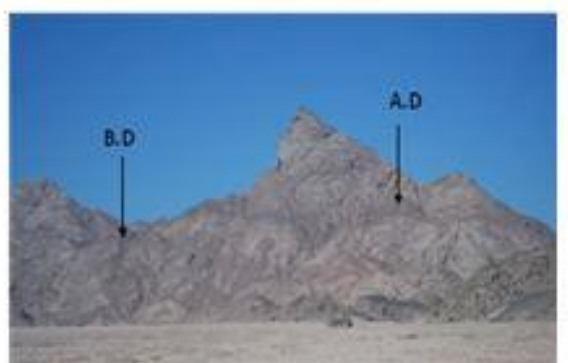

Fig10.Basic (B.D) and acidic (A.D) dikes intruding Ras Baroud younger granites.

Generally, geologically Abu Hadeida area was affected by tectonism relative to Ras Baroud area, which led to the formation of many alteration zones that contain many mineral associations, especially radioactive ones.

\subsection{Petrographical Studies}

Abu Hadeida granites are mainly composed of potash feldspars, quartz, micas and rare crystals of plagioclase. They are characterized by equigranular texture and occasionally catalyzed showing granulation of quartz and potash feldspars. Potash feldspars present as anhedral crystals of string perthite (Fig.12) and microlcline perthite. Microcline is also present as anhedral crystals. Some crystals of potash feldspars are hematitized and sericitized (Fig.13). Quartz represents about 25\%$30 \%$ of the rock. Mica minerals are rarely present occurring as secondary biotite mantling the opaque minerals or as primary muscovite enriched by iron oxides. plagioclase is completely absent or rare.

Zircon is the main accessory mineral displaying different forms and habits. It occurs as individual well-formed zoned crystals (Fig.14) or as twinned crystals included in perthite (Fig.15). Some crystals of zircon are characterized by inclusions of opaque minerals (Fig.16). Other crystals are partially metamictaized referring to presence of radionuclides (Fig.17).

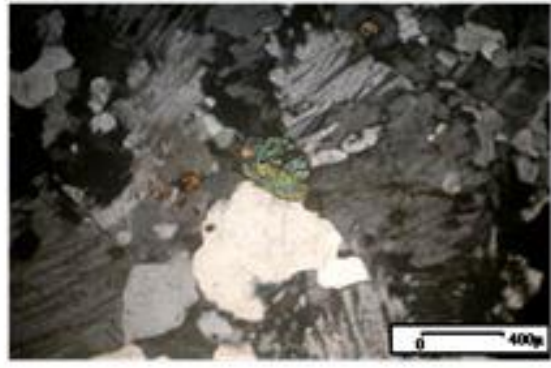

Figl2. Xenotim crystal with anhedral crystals of string perthite in Abu Hadeida granites. $x=20 . \mathrm{CN}$.

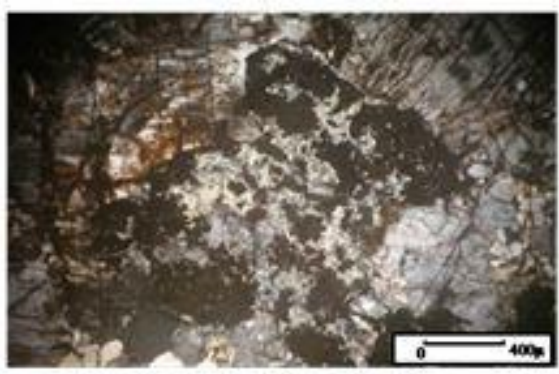

Figl3. Hematitization and sericitization of perthite in Abu Hadeida granites. $x=20 . C N$. 


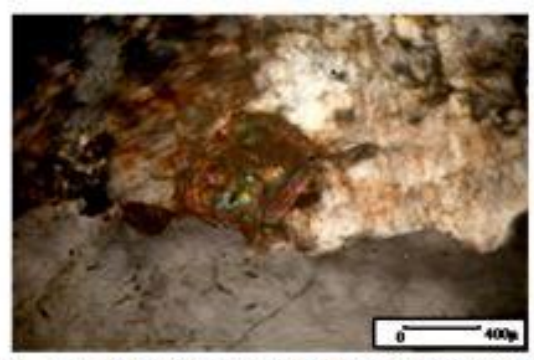

Figl4. A well-formed crystal of zoned zircon in $A b u$ Hadeida granites. $x=20 . C N$.

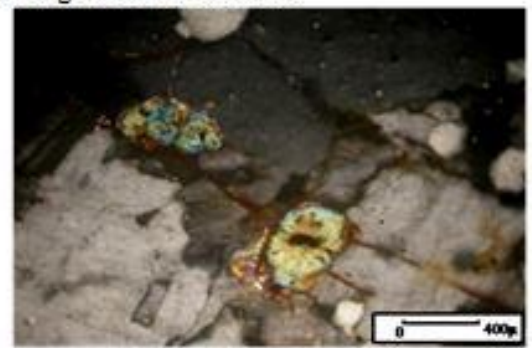

Figl6. Zircon with opaque inclusion in Abu Hadeida granites $x=20 . C N$

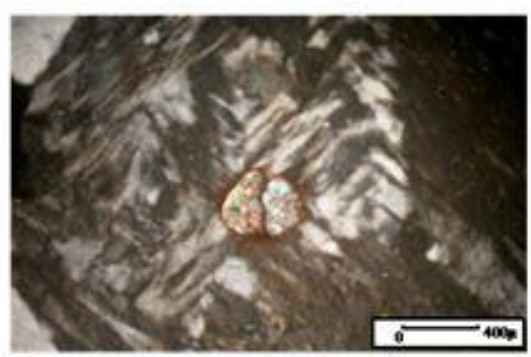

Figl5. Zircon crystals showing parallel twining in Abu Hadeida granites. $x=20 . C N$.

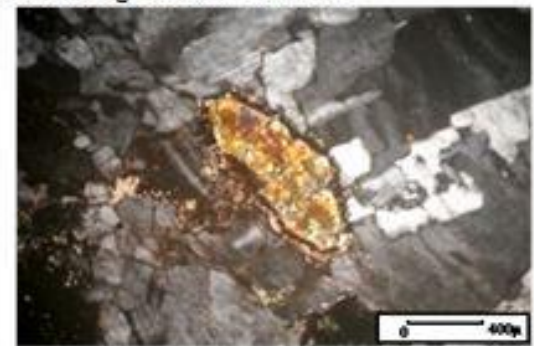

Fig17. Partially metamectized zircon in Abu Hadeida granites. $x=20 . C N$

Allanite is present as yellow crystal associating iron oxides or partially metamectized leaking the interference colors by the effect of radionuclides (Fig.18). Kasolite is also present as well-formed crystals characterized by orange color and opaque inclusions may be thorite (Fig.19).Uranophane is the main uranium mineral filling the cavities and associated with or coated by the secondary iron oxides (Fig.20) referring to epigenetic origin. Curite occurs as orangish red minute crystals associating uranophane and coated with iron oxides (see fig.20). Opaques occur in considerable amounts and highly increase in the mineralized zones.

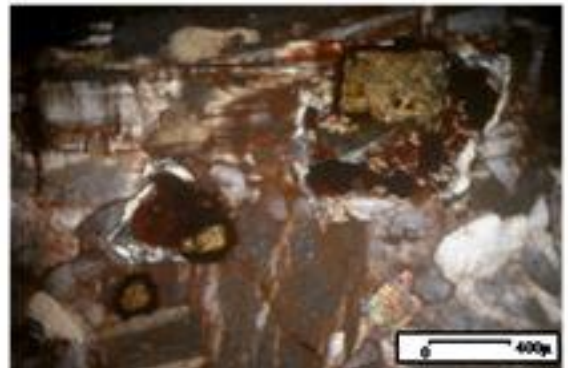

Fig18. Metanectized allanite crystals coated by iron oxides in $A b u$ Hadeida granites. $x=20 . C N$.

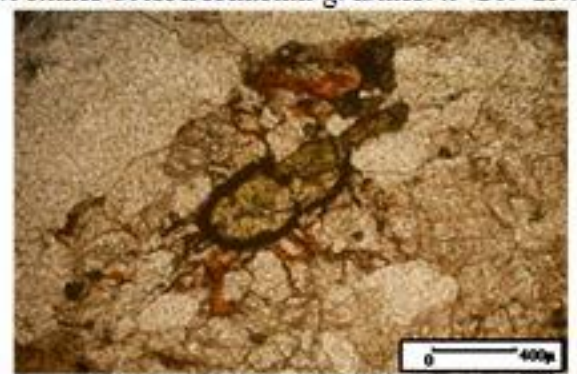

Fig20. Secondary wranophane and curite coated

with iron oxides in Abu Hadeida granites. $x=20 . P l$

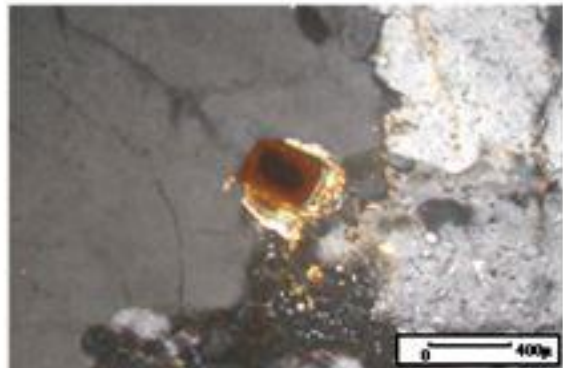

Fig19. A well-formed crystal of kazolite with opaque inclusion in Abu Hadeida granites. $x=20 . C N$.

Ras Baroud granite is medium to coarse grained and composed mainly of K-feldspars which represented by microcline perthite (Fig.21) and microcline. Plagioclase occurs as euhedral crystals of blade-like forms and showing lamellar twinning (Fig.22). Quartz is anhedral to subhedral crystal with undulose extention (Fig.23) and micas which represented by biotite and muscovite. On the other hand, accessory minerals are represented by Zircon which found in prismatic crystal and may surrounded by black hallows probably due to radioactive elements (Fig.24), titanite is a secondary mineral and associated with chlorite (Fig.25) and opaques. 
Through the petrographic studies of the two studied areas, it was observed that Abu Hadeida granite differs from Ras Baroud granite in the absence or scarcity of the plagioclase mineral, while Abu Hadeida granite is distinguished in that it contains many accessory minerals such as zircon, allanite and others more than Ras Baroud, these minerals are characterized by the presence of the metamict property, which indicates that these minerals contain radioactive elements in their chemical composition. As for the secondary minerals, especially uranium minerals (uranophan, curite, and kasolite) in Abu Hadeida, they are more present and widespread than Ras Baroud, this gives clear indication that Abu Hadeida granite emanated from a magma rich in magmatic minerals, as well as this granite was affected by a series of hydrothermal solutions that had a major impact on the formation of secondary minerals, especially Uranium minerals are more than the Ras Baroud granite, in which the magmatic minerals are reduced and were not affected by the hydrothermal solutions, which led to a lack of the presence of secondary minerals that characterize advanced granites. This is why Abu Hadeida granite is considered one of the most promising granites for extracting radioactive minerals.

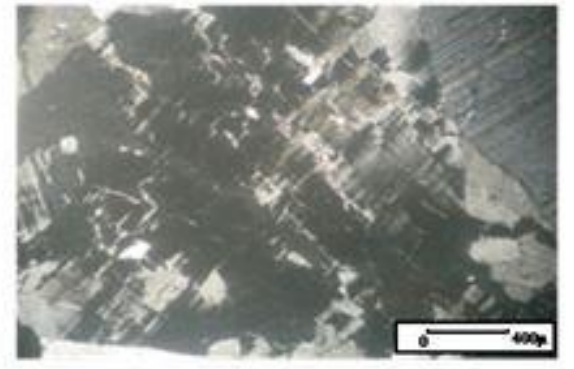

Fig21. Subhedral crystal of microcline perthite associating plagioclase and quart in RasBaroud granites. $X=20, C N$.

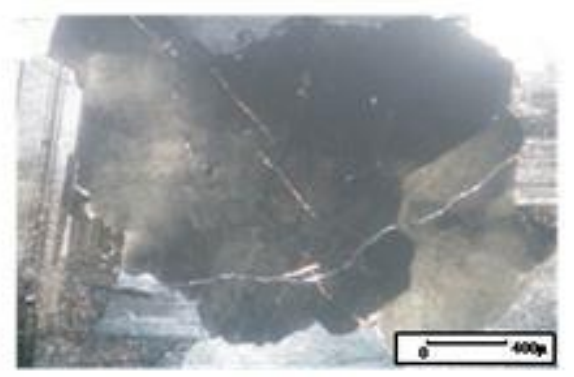

Fig23. Anhedral crystal of quart with undulose extention associating plagioclase in RasBaroud granite $X=10 . C N$.

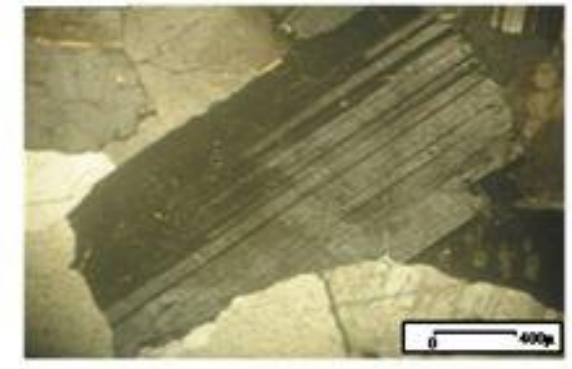

Fig22. Blade-like plagioclase crystals with albitic twinning in Ras Baroud granite. $X=20 . C N$.

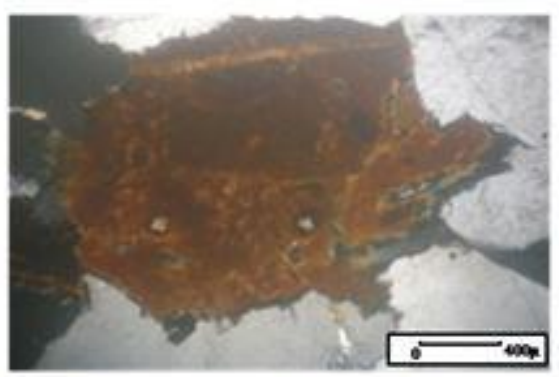

Fig24. Minute crystals of zircon surrounded by pleochroic hallows in biotite crystal in Ras Baroud granite. $X=20 . C N$.

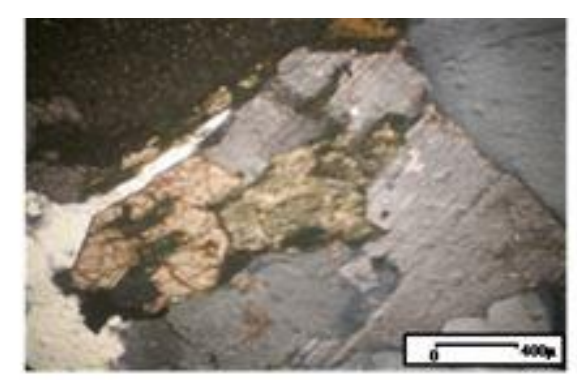

Fig25. Titanite crystal associated with chlorite in Ras Baroudgranite. $X=20 . C N$.

\section{GAMMA RAY SPECTROMETRY INVESTIGATIONS}

For regional in-situ field spectrometric measurements using a portable gamma-ray spectrometer Model RS-230 was accomplished along Ras Baroud and Abu Hadeida granites. Before field measurements the spectrometer is calibrated on concrete pads containing known concentrations of $\mathrm{K}$, $\mathrm{U}$ and Th. This calibration provides for correction of the measured $\mathrm{K}$, eU and eTh. The term "equivalent" or its abbreviation " $\mathrm{e}$ " is used to indicate that equilibrium is assumed between the radioactive daughter isotope monitored by the spectrometer, and its relevant parent isotope. $\gamma$-rays 
emitted by $214 \mathrm{Bi}$ at $1.76 \mathrm{MeV}$ were measured for $238 \mathrm{U}$ and gamma rays emitted by $208 \mathrm{TI}$ at 2.41 $\mathrm{MeV}$ were measured for $232 \mathrm{Th}$. Within the detector, an internal 137Cs source allows the spectrometer to automatically maintain system stability is measured over a large body of water.

The resulted radiometric data were found in table (1) to know the distribution of radioelements and their ratios in the compared rocks in the two localities. These measurements show that eU ranges from 14.5 to $28.4 \mathrm{ppm}$, eTh ranges from 32.9 to $46.5 \mathrm{ppm}$ and eU/eTh ratio ranges from 0.37 to 0.86 in Ras Baroud granite. While in Abu Hadeida granite eU ranges from 42.3 to $98 \mathrm{ppm}$, eTh ranges from 215 to $471 \mathrm{ppm}$ and eU/eTh ratio ranges from 0.15 to 0.262 . The noteworthy thing is that the studied rocks belong to high thorium-high uranium granites, reflecting the effect of hydrothermal solution rich in these radioelements. Normally, thorium is three times as abundant as uranium in rocks (Rogers and Adams, 1969). When this ratio is disturbed, it indicates a depletion or enrichment of uranium. The studied Ras Baroud granite samples show eTh/eU average ratios lower than 3 (1.84), suggesting the addition of uranium during secondary processes affecting the rocks. On contrast, Abu Hadeida granites have eTh/eU average ratios higher than 3 (5.22), which may clarify uranium migration out.

Table1. K\%, eU, eTh and their ratios of Ras Baroud and Abu Hadeida granites

\begin{tabular}{|c|c|c|c|c|c|c|c|c|}
\hline \multicolumn{9}{|c|}{ Ras Baroud granite } \\
\hline S.No. & $\mathbf{K} \%$ & eUppm & eThppm & eTh/K & eU/eTh & eTh/eU & eTh/3.5 & eU-(eTh/3.5) \\
\hline 1 & 3.1 & 22.6 & 46.5 & 15 & 0.49 & 2.06 & 13.29 & 9.31 \\
\hline 2 & 2.9 & 28.4 & 41.6 & 14.35 & 0.68 & 1.46 & 11.89 & 16.51 \\
\hline 3 & 3.6 & 16.8 & 36.7 & 10.19 & 0.46 & 2.18 & 10.49 & 6.31 \\
\hline 4 & 2.5 & 14.5 & 32.9 & 13.16 & 0.44 & 2.27 & 9.4 & 5.1 \\
\hline 5 & 4 & 19.4 & 38.3 & 9.58 & 0.51 & 1.97 & 10.94 & 8.46 \\
\hline 6 & 2.7 & 21.8 & 40.2 & 14.89 & 0.54 & 1.84 & 10.49 & 10.31 \\
\hline 7 & 2.2 & 25.6 & 37.6 & 17.09 & 0.68 & 1.47 & 10.74 & 14.86 \\
\hline 8 & 3.6 & 27.7 & 42.1 & 11.69 & 0.66 & 1.52 & 12.03 & 15.67 \\
\hline 9 & 3.1 & 20.6 & 39.8 & 12.84 & 0.52 & 1.93 & 11.37 & 9.23 \\
\hline 10 & 3.3 & 17.9 & 35.2 & 10.67 & 0.51 & 1.97 & 10.06 & 7.84 \\
\hline 11 & 2.8 & 24.1 & 36.2 & 12.93 & 0.67 & 1.5 & 10.34 & 13.76 \\
\hline 12 & 3 & 23.6 & 35.8 & 11.93 & 0.66 & 1.52 & 10.23 & 13.37 \\
\hline 13 & 4 & 28.4 & 32.9 & 8.23 & 0.86 & 1.16 & 9.4 & 19 \\
\hline 14 & 3.7 & 21.85 & .46 .5 & 12.57 & 0.47 & 2.13 & 13.29 & 8.56 \\
\hline 15 & 2.2 & 14.5 & 38.74 & 17.61 & 0.37 & 2.67 & 11.07 & 3.43 \\
\hline Av. & 3.11 & 21.85 & 38.74 & 12.85 & 0.57 & 1.84 & 11.07 & 10.78 \\
\hline \multicolumn{9}{|c|}{ Abu Hadeida granite } \\
\hline 1 & 2.8 & 61.7 & 312 & 111.43 & 0.198 & 5.06 & 89.14 & -27.44 \\
\hline 2 & 4 & 91 & 471 & 117.75 & 0.193 & 5.18 & 134.57 & -43.57 \\
\hline 3 & 6.5 & 68.8 & 402.2 & 61.88 & 0.171 & 5.85 & 114.91 & -46.11 \\
\hline 4 & 4.7 & 45.6 & 304 & 46.68 & 0.150 & 6.67 & 86.86 & -41.26 \\
\hline 5 & 5.5 & 55.3 & 325 & 59.09 & 0.170 & 5.88 & 92.86 & -37.56 \\
\hline 6 & 5 & 98 & 446.8 & 89.36 & 0.219 & 4.56 & 127.66 & -29.66 \\
\hline 7 & 6.7 & 92.4 & 352.8 & 52.66 & 0.262 & 3.82 & 100.8 & -8.4 \\
\hline 8 & 8.7 & 97 & 463 & 53.22 & 0.210 & 4.77 & 132.29 & -35.29 \\
\hline 9 & 4.2 & 49.9 & 231 & 55 & 0.216 & 4.63 & 66 & -16.1 \\
\hline 10 & 5.1 & 51.3 & 233 & 45.69 & 0.220 & 4.54 & 66.57 & -15.27 \\
\hline 11 & 5.2 & 42.3 & 215 & 41.35 & 0.197 & 5.08 & 61.43 & -19.13 \\
\hline 12 & 4.7 & 53.6 & 243.6 & 51.83 & 0.220 & 4.54 & 69.6 & -16 \\
\hline 13 & 7.7 & 91.8 & 410 & 53.25 & 0.224 & 4.47 & 117.14 & -25.34 \\
\hline 14 & 4.4 & 73.1 & 420 & 95.46 & 0.174 & 5.75 & 120 & -46.9 \\
\hline 15 & 4.5 & 47.8 & 298 & 66.22 & 0.160 & 6.23 & 85.14 & -37.34 \\
\hline 16 & 4.9 & 59.4 & 336.2 & 68.61 & 0.177 & 5.66 & 96.06 & -36.65 \\
\hline 17 & 5 & 65.4 & 389.7 & 77.94 & 0.168 & 5.96 & 111.34 & -45.94 \\
\hline 18 & 4.7 & 76.9 & 428.9 & 91.26 & 0.179 & 5.58 & 122.54 & -45.64 \\
\hline 19 & 5.1 & 79.4 & 443.1 & 86.88 & 0.179 & 5.58 & 126.6 & $\begin{array}{l}-47.2 \\
\end{array}$ \\
\hline 20 & 5.3 & 82.7 & 399.4 & 75.36 & 0.207 & 4.83 & 114.11 & -31.41 \\
\hline 21 & 4.8 & 87.3 & 439.8 & 91.63 & 0.199 & 5.04 & 125.66 & -38.36 \\
\hline Av. & 5.21 & 70.03 & 360.21 & 71.93 & 0.195 & 5.22 & 102.9 & -32.86 \\
\hline
\end{tabular}


eU-eTh Variation Diagram show that all Abu Hadeida samples lie around the line of eTh/eU ratio equal 5 with direct relation between the two elements, suggesting their distributions are mainly magmatic. While Ras Baroud samples have lower eTh/eU with no clear relation between the two elements, indicating that the radioelements distribution in this locality may be essentially controlled by hydrothermal solutions (Fig.26).U/Th increases with differentiation and the highest U/Th ratio occurs in the more differentiated rocks (Chatterjee and Muecke,1982; Saleh, et al. 2013).

eU-(eU/eTh) Diagram there is a direct relation between $\mathrm{eU}$ and eU/eTh ratio in which eU/eTh increase with eU increasing in both two granites but Ras Baroud granite has high U-enrichment with low eU/eTh values but Abu Hadeida granite has lower U and higher thorium and consequently lower eU/eTh values (Fig.27), this indicate that $U$ may migrated and precipitate in the adjacent rocks, especially in the microgranitic offshoots.

eU/eU-(eTh/3.5) Diagram this relation show the mobilization of uranium in both two granite. From (Fig.28) we note that Ras Baroud has U-enrichment but Abu Hadeida granite show U-depletion, this means that uranium in Abu Hadeids may be migrated and precipitated in the weak planes of the adjacent rocks, especially the microgranitic offshoots.

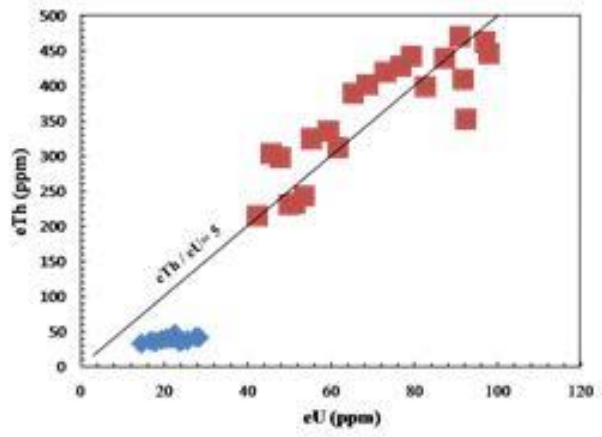

Fig.26.eTh - eUvariation diagram of Ras Baroud and Abu Hadeida granites.

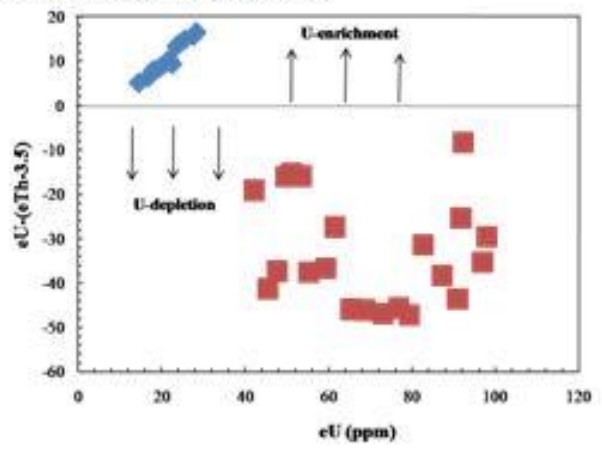

Fig.28.eU-(eU-eTh/3.5) variation diagram of Ras Baroud and Abu Hadeida granites

- Abu Hadeida.

- RasBaroud

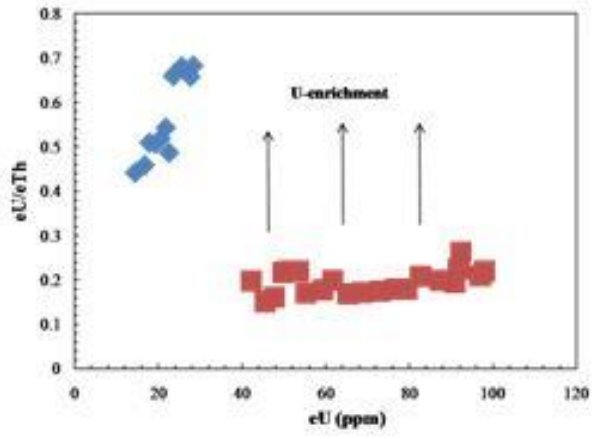

Fig27.eU - (eU/eTh) variation diagram of Ras Baroud and Abu Hadeida granites.

The wide ranges of $\mathrm{eTh} / \mathrm{K}$ ratio in the Abu Hadeida granitic rocks (41.35-117.75), comparing with the narrow range of this ratio in Ras Baroud granites (8.23-17.61),

illustrate that Abu Hadeida granitic rocks have a very high U potential mobilization than Ras Baroud granites which have lower U-mobilization (Saleh et al., 2018).

\section{Mineralogical Studies}

Three samples were taken from Ras Baroud granite and five samples from Abu Hadeida granites . These samples crushed to different size ranging from $1 \mathrm{~mm}$ to $0.63 \mathrm{~mm}$, washed by $\mathrm{H}_{2} \mathrm{O}_{2}$, and $\mathrm{HCl}$, then drayed. A representative sample of about $60 \mathrm{gm}$ from each sample was separated by heavy liquid bromoform $2.88 \mathrm{gr} / \mathrm{cm}^{3}$.

Mineralogical investigation of the mineral constituents of the samples was carried out by using binocular stereomicroscope. Semi quantitative EDX chemical analyses were also carried out using a 
Phillips XL-30 Environmental Scanning Electron Microscope (ESEM). All these analysis were carried out in the laboratories of the Nuclear Materials Authority (NMA), Egypt.

Abu Hadeida granite has several important heavy minerals. These minerals include fluorite, zircon, columbite, samarskite, curite and uranophan.

Fluorite occurs as transparent to translucent crystals that range in color from colorless, blue to deep violet (Fig.29). The color variation may be attributed to the presence of radionuclides in the associated minerals or to the trace element content (Raslan,2009).

Zircon is a common accessory mineral in a wide range of rocks, particularly in felsic igneous rocks (Hoskin \& Schaltegger, 2003).The studied zircon occurs as pale to dark brown massive compact grains that are generally translucent to opaque(Fig.30).Some crystals are characterized by sieve texture due to inclusions of other minerals especially radioactive ones.

columbite is Nb-dominant, and the tantalite subgroup is Ta-dominant. They contain $\mathrm{U}$ and $\mathrm{Th}$ in various amounts and are commonly metamict. Columbite is commonly occupied by $\mathrm{Mg}^{2+}$ (magnesiocolumbite), $\mathrm{Fe}^{2+}$ (ferrocolumbite) which the studied columbite is belonging to, and $\mathrm{Mn}^{2+}$ (manganocolumbite), while $\mathrm{U}$ and $\mathrm{Th}$ substitutions are relatively minor. Columbite is generally black in color and possess a brilliant metallic luster and occurs as irregular elongated angular grains with sharp edges(Fig.31).

Samarskite is Nb-Ta mineral having Fe2+, Ca, REE, Y, U and Th. (Hanson et al. 1999), proposed a nomenclature for the samarskite group of minerals based on their classification into three species, if the REE+Y are the dominant, the name samarskite-(REE+Y) should be used. If U+Th are the dominant, the mineral is properly named ishikawaite and if $\mathrm{Ca}$ is the dominant cation, the mineral should be named calciosamarskite. samarskite crystals are generally massive with granular form and having a characteristic vitreous luster and exhibit reddish brown to dark brown color (Fig.32).Although most crystals often possess granular form, however, some crystals are present as massive rod-like and tabular crystals.

Curite occurs as massive to fibrous fine to very fine grains. It exhibits yellow to brownish yellow color with waxy luster(Fig.33).(Heinrich, 1958) mentioned that curite is a rare supergene alteration of pitchblende, and $\mathrm{Pb}$ may be derived from galena or may be radiogenic.

Uranophane occurs as massive, granular and sometimes radiated fibrous aggregates and exhibit canary yellow to reddish yellow color with dull to greasy luster (Fig.34). The conditions of formation of this mineral include both the late stages reactions of uraninite with hydrothermal solutions and also alteration by groundwater(Finch and Ewing, 1992).

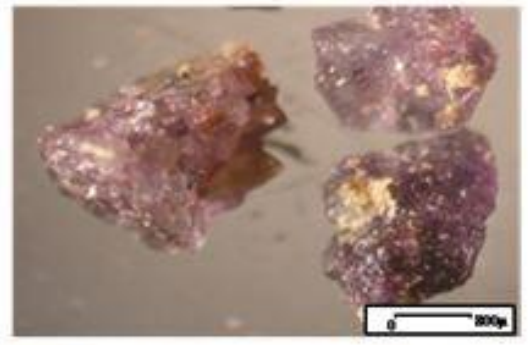

Fig29. Violet fluorite in Abu Hadeida granite.

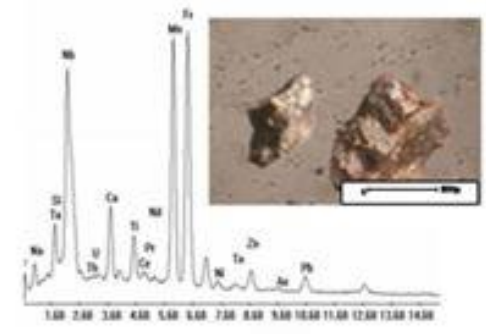

Fig31. Black to brownish blackgrains of columbite mineral in Abu Hadeida granite.

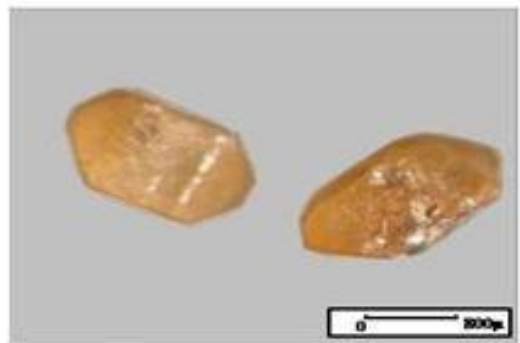

Fig30. Prismatic crystal of zircon in Abu Hadeida granite.

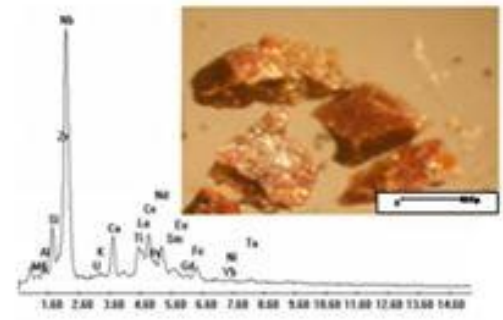

Fig.32.reddish brown to dark brown grains of samarskite mineral in Abu Hadeida granite. 


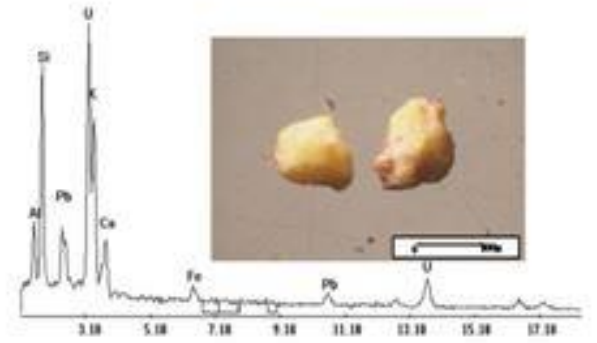

Fig33. Yellow to brownish yellow grain of curite mineral in Abu Hadeida granite.

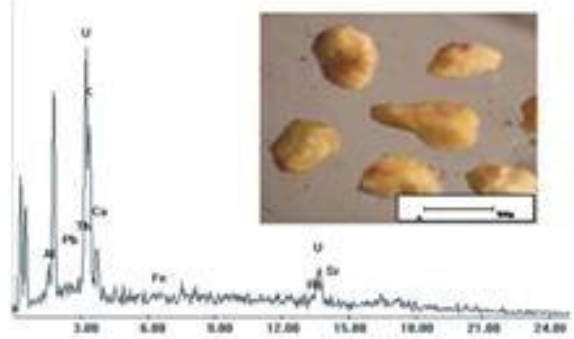

Fig 34. Canary yellow to reddish yellow grains of uranophane in Abu Hadeida granite.

In Ras Baroud granite, $\mathrm{Nb}$ - $\mathrm{Ta}$ anomalies exist in the granite itself associating the pegmatitic bodies (Mahdy, et al.,1991). The anomalies values of $\mathrm{Nb}$, Ta may be found as disseminated $\mathrm{Nb}-\mathrm{Ta}$ minerals or associated with lattice of mica or other minerals.

Two modes of mineralization are recognized in Ras Baroud granite (Omar, 1995), these are:

a)Free of radioactive anomalies where $\mathrm{Nb}$-Ta mineralization occurs as cluster of fan-shaped prismatic crystals of columbite -tantalite or alvalorite.

b)Associated with anomalies radioactivity, where the mineralization occurs as invisible disseminations in feldspars. So, the most important minerals in Ras Baroud granite are:

Columbite is found as anhedral tabular grains with black to brownish black color(Fig.35) and has cleavages in two directions(Fig.36).

Zircon is found in normal state with no evidence for radioactivity(Fig.37), and titanite are also found in Ras Baroud granite.

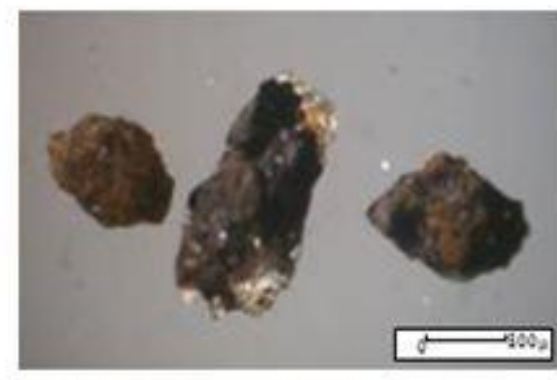

Fig35. Prismatic crystal of black columbite in Ras Baroud granite.

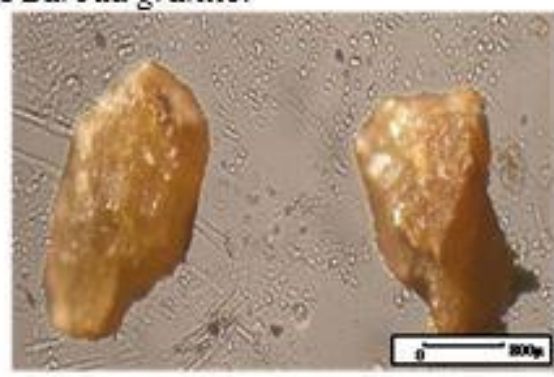

Fig 37. Prismatic crystals of zircon in Ras Baroudgranite.

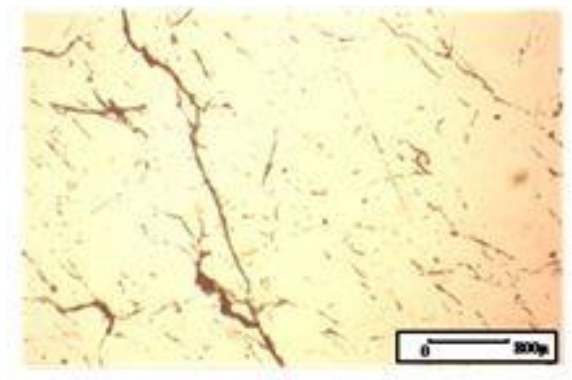

Fig36. Two directions of cleavage in columbite crystal of Ras Baroud granite.

On the other hand, Ras Baroud pegmatite was characterized by the mineral assemblage including; samarskite, columbite, cassiterite, zircon, fluorite and rutile (Abdelmonsif,et al.,2018). Pegmatite in Ras Baroud is characterized by containing many economic minerals as a result of its exit from a magma rich in important elements and minerals, unlike younger granite (our target) that emerged from a poor magma in economic elements and minerals

Through mineral studies of the studied areas, it became clear to us that Abu Hadeida granite is one of the most important younger granites that contain many minerals of high economic value, especially 
radioactive minerals or minerals that carry radioactive elements compared to Ras Baroud granite, which lacks these minerals. The presence of these minerals in Abu Hadeida and their absence from Ras Baroud is due to the richness of the molten magma that emanates from the Abu Hadeida granite with magmatic minerals that have the ability to carry or contain radioactive elements, as well as the influence of these granites with many external and internal processes that have had a clear impact on the formation of many economic minerals.

\section{TRACE ELEMENTS GEOCHEMISTRY}

The trace elements in granitic rocks are classified into metallogenic elements, that tend to be associated with the processes of mineralization as $\mathrm{Sn}, \mathrm{W}, \mathrm{Mo}, \mathrm{Cu}, \mathrm{Li}, \mathrm{Be}, \mathrm{Pb}, \mathrm{Zn}, \mathrm{Au}, \mathrm{U}, \mathrm{Ag}, \mathrm{F}$ and $\mathrm{Cl}$ and petrogenic elements associated with the normal magmatic processes of granitic melts as $\mathrm{Rb}, \mathrm{Ba}$, $\mathrm{Sr}, \mathrm{Y}, \mathrm{Zr}, \mathrm{Nb}, \mathrm{Ta}, \mathrm{Pb}, \mathrm{Sc}, \mathrm{Ga}, \mathrm{REE}$, and Th. Some of the petrogenic elements as $\mathrm{Ba}, \mathrm{Nb}$, Ta, Th and REE may become highly enriched during mineralization processes and form mineral deposits.

Ten samples from Abu Hadeida granites and eight samples from Ras Baroud granite were studied geochemically as shown in (Table 2), which show that Abu Hadeida granite has high concentrations of $\mathrm{Nb}, \mathrm{Zr}$ and $\mathrm{Y}$ compared with Ras Baroud granite, this indicates that Abu Hadeida granite is alkaline to peralkaline typology (Cuney, 1997).

Through (table 2), we note that all the trace elements in Abu Hadeida granite have higher concentrations than Ras Baroud granite except two elements: barium which is attributed to the formation of the plagioclase mineral in Ras Baroud granite and its disappearance or its scarcity in Abu Hadeida granite and the second element is copper. Ras Baroud granite has low concentration of $\mathrm{Zr}$, $\mathrm{Rb}, \mathrm{Y}, \mathrm{Ba}, \mathrm{Pb}$ and $\mathrm{Nb}$ than the associated pegmatites while $\mathrm{Cu}$ and $\mathrm{Sr}$ elements exhibit high concentration in granite compared with pegmatites (Abdelmonsif, et al., 2018).

Table2. Trace Elements geochemistry of Ras Baroud and Abu Hadeida granites

\begin{tabular}{|c|c|c|c|c|c|c|c|c|c|c|c|c|c|}
\hline & \multicolumn{10}{|c|}{ Ras Baroud granite } \\
\hline S.No. & $\mathrm{Cu}$ & $\mathrm{Zn}$ & $\mathrm{Zr}$ & $\mathrm{Rb}$ & $\mathrm{Y}$ & $\mathrm{Ba}$ & $\mathrm{Pb}$ & $\mathrm{Sr}$ & $\mathrm{Nb}$ & $\mathrm{Rb} / \mathrm{Sr}$ & $\mathrm{Ba} / \mathrm{Rb}$ & $\mathrm{U}$ & $\mathrm{Th}$ \\
\hline 1 & 51 & 19 & 139 & 49 & 28 & 186 & 5 & 72 & 27 & 0.68 & 3.8 & 41 & 54 \\
\hline 2 & 49 & 98 & 248 & 71 & 22 & 639 & 8 & 81 & 18 & 0.88 & 9 & 63 & 65 \\
\hline 3 & 36 & 55 & 189 & 61 & 24 & 508 & 4 & 81 & 34 & 0.75 & 8.3 & 60 & 64 \\
\hline 4 & 34 & 45 & 144 & 105 & 31 & 239 & 5 & 89 & 36 & 1.17 & 2.3 & 43 & 55 \\
\hline 5 & 50 & 21 & 81 & 76 & 21 & 325 & 6 & 112 & 28 & 0.68 & 4.3 & 34 & 51 \\
\hline 6 & 33 & 81 & 128 & 52 & 29 & 179 & 3 & 41 & 31 & 1.27 & 3.4 & 33 & 57 \\
\hline 7 & 38 & 77 & 129 & 141 & 40 & 268 & 55 & 79 & 38 & 1.78 & 1.9 & 36 & 43 \\
\hline 8 & 36 & 79 & 149 & 109 & 42 & 249 & 16 & 49 & 43 & 2.22 & 2.3 & 54 & 62 \\
\hline Av. & 40.9 & 59.4 & 151 & 83 & 29.6 & 324.1 & 12.8 & 75.5 & 31.9 & 1.2 & 3.9 & 45.5 & 56 \\
\hline & \multicolumn{10}{|c|}{ Abu Hadeida granite } \\
\hline 1 & 11 & 335 & 4110 & 301 & 1825 & 105 & 79 & 135 & 671 & 2.23 & 0.35 & 522 & 2009 \\
\hline 2 & 16 & 166 & 4624 & 248 & 2155 & 88 & 47 & 169 & 785 & 1.47 & 0.35 & 595 & 2370 \\
\hline 3 & 39 & 582 & 7366 & 318 & 3211 & 68 & 153 & 243 & 1246 & 1.31 & 0.21 & 658 & 2812 \\
\hline 4 & 6 & 169 & 9987 & 246 & 5082 & 54 & 359 & 398 & 1878 & 0.62 & 0.22 & 682 & 2840 \\
\hline 5 & 9 & 960 & 4140 & 109 & 1873 & 98 & 78 & 138 & 681 & 0.79 & 0.9 & 538 & 2180 \\
\hline 6 & 7 & 139 & 6188 & 264 & 2698 & 61 & 64 & 214 & 989 & 1.23 & 0.23 & 624 & 2415 \\
\hline 7 & 4 & 254 & 7288 & 111 & 3198 & 29 & 389 & 249 & 1214 & 0.45 & 0.26 & 644 & 2698 \\
\hline 8 & 12 & 259 & 3968 & 122 & 1774 & 115 & 52 & 138 & 682 & 0.88 & 0.94 & 498 & 1982 \\
\hline 9 & 5 & 978 & 9898 & 88 & 5389 & 123 & 128 & 432 & 1989 & 0.20 & 1.4 & 698 & 2904 \\
\hline 10 & 7 & 422 & 9967 & 243 & 4528 & 84 & 332 & 354 & 1894 & 0.68 & 0.35 & 702 & 2989 \\
\hline Av. & 11.6 & 426.4 & 6753.6 & 205 & 3173.3 & 82.5 & 168.1 & 247 & 1202.9 & 0.98 & 0.4 & 616 & 2520 \\
\hline
\end{tabular}

\subsection{Rb-Sr Diagram}

The strontium distribution in igneous rocks is controlled by the extent to which $\mathrm{Sr}^{2+}(1.13 \AA)$ can substitute for $\mathrm{Ca}^{2+}(0.99 \AA)$ in calcium-bearing minerals and the degree to which potassium feldspar can capture $\mathrm{Sr}^{2+}$ in the $\mathrm{K}^{+}$sites. So, the principal carriers of $\mathrm{Sr}$ in igneous rocks are plagioclase feldspar and apatite. The $\mathrm{Rb}$ increases and the $\mathrm{Sr}$ decreases during the magmatic differentiation.(Fig.38) show that $\mathrm{Rb}$ and $\mathrm{Sr}$ in Ras Baroud are smaller than that in Abu hadeida which 
mean that Abu Hadeida granite is more differentiated than Ras Baroud. On the other hand, $\mathrm{Sr}$ in $\mathrm{Abu}$ Hadeida become high in concentration which may be the effect of hydrothermal solution on the granite.

\subsection{Ba-Sr Diagram}

The $\mathrm{Ba}$ and $\mathrm{Sr}$ elements decrease continuously from less evolved samples to the most evolved samples.(Fig.39) show that all samples of Abu Hadeida granite lie below $\mathrm{Ba} / \mathrm{Sr}=1$ are the most evolved samples but Ras Baroud samples lie over $\mathrm{Ba} / \mathrm{Sr}=1$ are more less evolved samples.

\subsection{Nb-Y Diagram}

Pearce et al.,(1984) used the trace elements to discriminate the tectonic environments of granitic rocks. They concluded that the granites can be classified according to their tectonic settings into four main groups; oceanic ridge granites (ORG), volcanic arc granites (VAG), within plate granites (WPG) and collision granites (COLLG). All samples of Abu Hadeida granite lie in the field of (WPG) but Ras Baroud samples are found in the field of (VAG+ Syn-COLG)(Fig.40).

The trace elements normalized to chondrite (Taylor and McLennan, 1985) plotted on the spider diagram (Fig.41).Both Ras Baroud and Abu Hadeida have high concentrations of trace elements rather than the chondrite except $\mathrm{Nb}, \mathrm{U}$ and $\mathrm{Th}$ in Ras Baroud which are depleted and characterized by negative anomaly referring to the uranium leach out, on the other hand, the trace elements of Abu Hadeida are higher than Ras Baroud especially the $U$ and $T h$ which indicate that uranium is enriched in Abu Hadeida granite.

The geochemical ratios $\mathrm{Ba} / \mathrm{Rb}$ vs $\mathrm{Rb} / \mathrm{Sr}$ used to evaluate the degree of evolution of the granitic pegmatite (Larsen 2002). (Fig.42) show that the samples of Ras Baroud follow the trend of evolved granite with very low grad, while those of Abu Hadeida follow the trend of more evolved granite with very high grad, this result refer to that Abu Hadeida granite is more evolved than Ras Baroud granite.

In conclusion, the high concentrations of trace element in Abu Hadeida granite and its decrease in Ras Baroud granite confirm the conclusions that we reached in petrographical and mineralogical studies, namely that Abu Hadeida granite emerged from a magma rich in the concentrations of elements and minerals of high economic value, especially this granite was exposed to many tectonic movements that led to more of these important minerals, which make Abu Hadeida granite one of the most promising granites in Egypt. It also confirms that this granite is one of the most promising types in Egypt, containing high concentrations of uranium and thorium, which leads us to confirm that this granite emanated from a magma rich in minerals, including radioactive minerals that may be sourced from the magma molten or by the following processes, including hydrothermal solutions that worked on precipitation those minerals in the form of easy to extract.

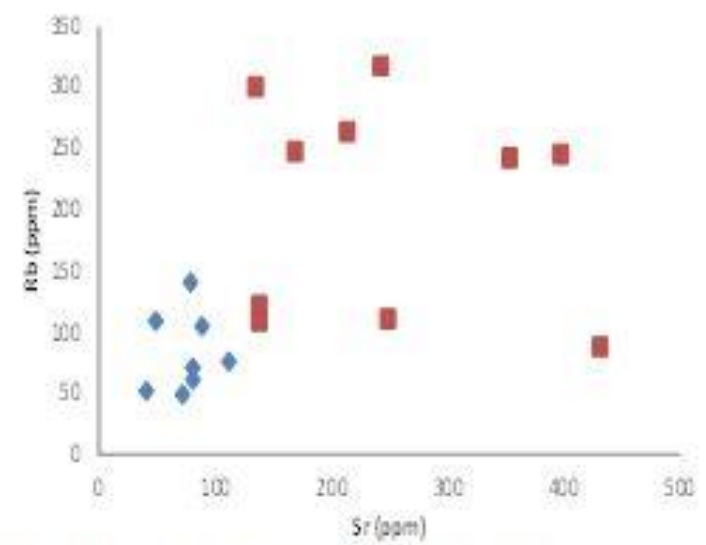

Fig38. Rb(ppm)-Sr(ppm) plot of the studied granites, (after Condie 1973).

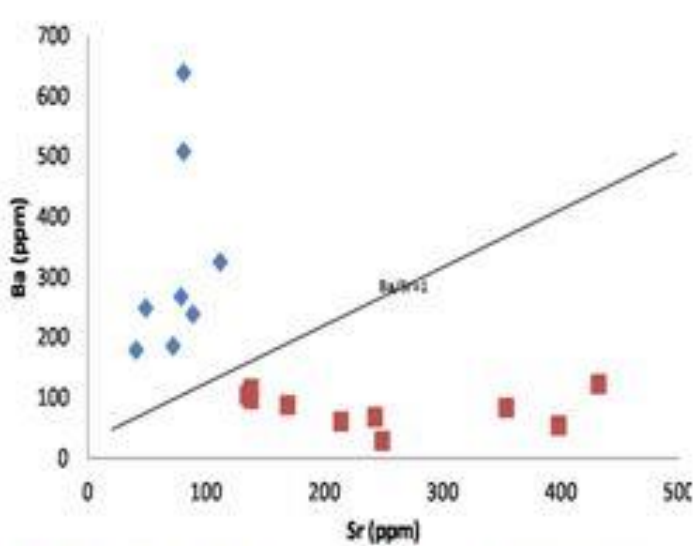

Fig39. $B \alpha(p p m)-S r(p p m)$ plot of the studied granites. 


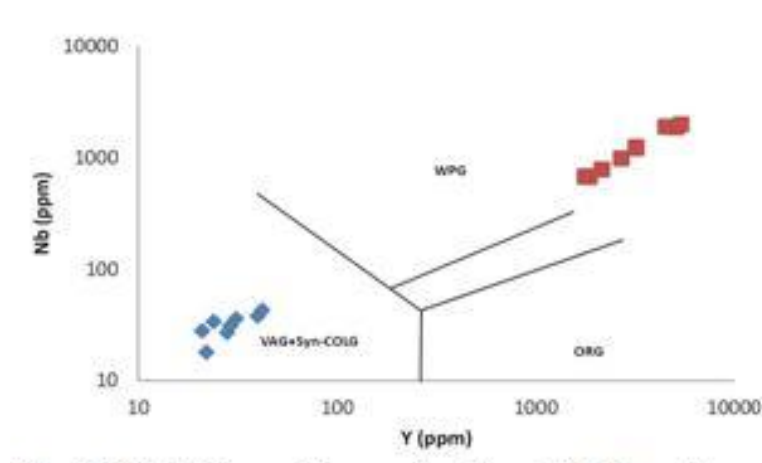

Fig40. $N b-Y$ binary diagram for the studied granites (after Preace et al., 1984).

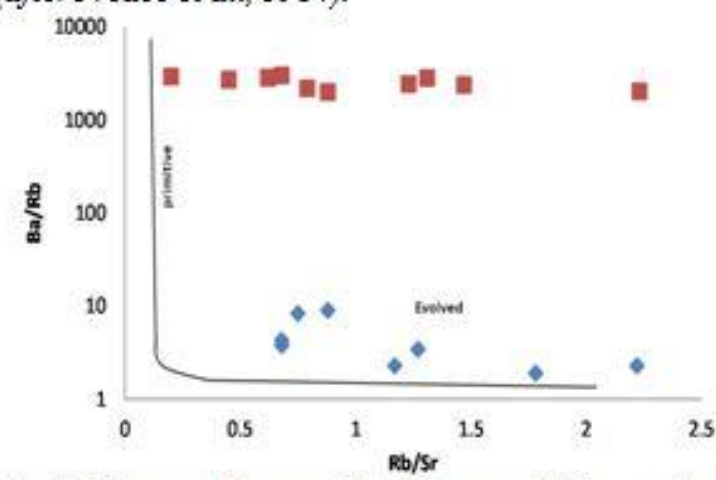

Fig42. Variation diagram of $B a R b$ ratio $v s R b / S r$ ratio for the studied granites.

- Abu Hadeida

RasBaroud

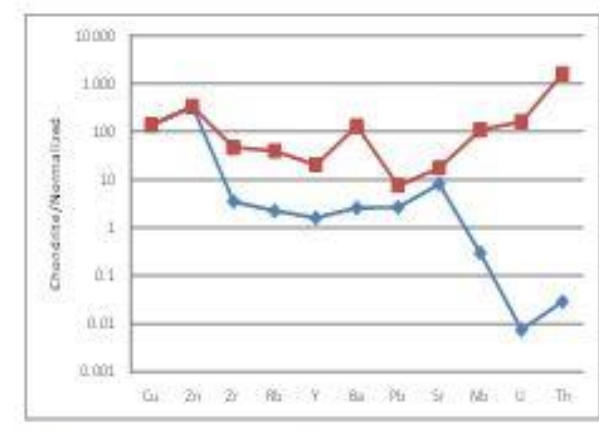

Fig41.Spider diagram of chondritenormalized trace elements for the studied granites.

\section{CONCLUSION}

Abu Hadeida area is highly tectonised in comparison with Ras Baroud, leading to the formation of many alteration zones that contain various types of mineral assosciations, especially radioactive minerals. It was observed that Abu Hadeida granite differs from Ras Baroud granite where it is vacant from the plagioclase. Abu Hadeida granite is distinguished its content of accessory minerals such as zircon, allanite and uranophan, curite, and kasolite relative to Ras Baroud. The trace elements content in Abu Hadeida granite are higher than Ras Baroud granite except barium, which is attributed to the presence of the plagioclase Ras Baroud granite and its disappearance or its scarcity in Abu Hadeida granite and the second element is copper, which is connected to the presence of sulphides. Radiometrically, Abu Hadeida granite is highly radioactive and comparatively more evolved relative to Ras Baroud granite. Uranium migration studies indicate uranium migration-out in Abu Hadeida granite, in contrast to Ras Baroud granite that shows U-migration in. Radioelements interrelationships illustrate that the distribution of these element is not only magmatic but also hydrothemal.

\section{REFERENCES}

Abdelmonsif, M., El Nahas, H. A., and Abdallah, S. M.(2018): Mineralogy and trace elements geochemistry of pegmatite body at the Northern periphery of Gabal Ras Baroud, Central Eastern Desert, Egypt. ISSN 2314-5609, Nuclear Sciences Scientific J. V.7. pp151-164.

Beus, A. A.(1982):Metallogeny of Precambrian rare-metal granitoids. Brazilian Reviews of Geosciences, 12, $410-413$.

Chatterjee, A.K and Muecke, G.K.(1982):Geochemistry and the distribution of uranium and thorium in the granitoids rocks of the South Mountain Batholith, Nova Scotia: some genetic and exploration implications. In: Mourice, Y.T. (Ed.), uranium in granites [M]. Paper 81-23. Geological Survey of Canada, Ottawa, pp. 11-17.

Cuney, M.(1997): Metallogenic studies and uranium exploration in E.D. granites, Egypt. IAEA, RU-729 p.

Condie, K. C.(1973):Archaean magmatism and crustal thickening. Geol. Soc. Am. Bull., Vol. 84, pp. 2981 2992. 
El Azab, A., Omran, A. and Hassan, A.H.(2014): Contribution to the mineralogy and radioactivity of stream sediments of wadi Ras Baroud area, North Eastern Desert, Egypt. Al Azhar Bulletine of Science Vol.(25)No.1, June,29-46ppm,2014.

El Feky, M. G.(2011): Mineralogical, REE-geochemical and fluid inclusion studies on some uranium occurrences, Gabal Gattar, Northeastern Desert, Egypt. Chin.J.Geochem., 30, 430-443.

El Hadary A,. ElAzab A., Omran A.A.(2013): Contributions to the geology and mineralogy of wadi Ras Abda area, North Eastern Desert, Egypt. Nuclear Sciences Scientific Journal. V. 2.

El Ramly, M. F.(1972): Anew geologic map for the basement rocks in the Eastern Desert and South Western Desert, Egypt . Annal . Geol . Surv., Egypt. V.II , pp 1-18

Finch, R.J. and Ewing, R. C.(1992):The corrosion of uraninite under oxidizing conditions. J. Nucl. Mater. Vol. 190, pp133-156.

Heinrich, E.W.(1958): Mineralogy and geology of radioactive raw materials. Mcgraw-hall book Company. INC. New York, Toronto,London. Pp 16-149.

Hanson, S.L., Simons, W.B., Falster, A.U., Foord, E.E., and Lichte F.E.(1999): Proposed nomenclature for samarskite-group minerals: new data on ishikawaite and calciosamarskite, Mineral. Mag., 63, $27-63$.

Hoskin, P. W. O. \&Schaltegger, U.(2003): The composition of zircon and igneous and metamorphic petrogenesis. In: Hanchar, J. M. \&Hoskin, P.W.O. (eds) Zircon. Reviews in Mineralogy and Geochemistry 53, pp27-62.

Hussein, H. A., Faris, M. I. and Makram, W.(1965): Radioactivity of some accessory minerals especially zircon in some Egyptian granites and pegmatites. J. Geol., U. A. R., 9, no. 2: pp 13-16.

Larsen, R. B.(2002): The distribution of rare-earth elements in K-feldspar as an indicator of petrogenetic processes in granitic pegmatites: examples from two pegmatite fields in southern Norway. The Canadian Mineralogist, Vol. 40, pp137-1512.

Mahdy, M.A., Assaf, H.S. and Omer, S.A.(1991): Geological and geochemical investigation of radioactive occurrence in Gebel Ras Baroud granitic mass, Central Eastern Desert, Egypt. Proceeding of African Mining.J, 91, Harare, Zimbabwe.

Omar, S.A.(1995): Geology and geochemical features of the radioactive occurrences of Um.Anab granitic masses, Eastern Desert, Egypt. M.Sc. thesis, Cairo University.164P

Omran, A. A.(2005): Geological, petrochemical studies and potentiality of uranium-thorium occurrences in Gabal Um Taghir El-Tahtani area with emphasis on the granitic rocks, Central Eastern Desert, Egypt. Ph.D. thesis, Ain Shams Univ., Cairo, Egypt. 189 p.

Omran, A. A.(2014):Geology, mineralogy and radioelements potentiality of microgranite dikes to the South of wadi Abu Hadieda area, Northern Eastern Desert, Egypt. Al AzharBulletine of Science Vol.(25) No.1,June, 47-62ppm.

Pearce, J. A., Harris, N. B. W., and Tindle, A. G.(1984): Trace element discrimination diagrams for the tectonic interpretation of granitic rocks. Jour. Petrol., Vol. 25, part 4, pp 956-983.

Raslan, M. F.(2009): Mineralogical and geochemical characteristics of uranium-rich fluorite in El-Missikat mineralized granite, Central Eastern Desert, Egypt. Geologia 52/2, 213-220

Rogers, J.J.W. and Adams, J.A.S.(1969): Uranium and thorium. In Handbook of Geochemistry (ed. Wedepohl K.H.) [M]. VII-3, 92-B-1 to 92-0-8 and 90-B-1 to 90-0-5, Springer Verlag, Berlin.

Rogers, J .J. W. and Greenberg, J. K.(1983): Summary of recent work on Egyptian younger granites. Ann. Geol. Surv. Egypt, V. 13, pp 185-191.

Sabet, T.H. and Tsogoev, V.B.(1973): Problems of geological and economic evaluation of tantalum deposits in apogranites during stages of prospection and exploration. Annals of the Geological Survey of Egypt, 3,pp 87.107.

Saleh, G. M. and Said A. El-Nisr (2013): Tow Mica Granites, Southeastern Desert, Egypt: Geochemistry and Spectrometric Prospecting. Greener Journal of Geology and Earth Sciences, 1, (2), 023-042.

Saleha, G.M., Afify, A.M., Emad, B.M., Dawoud, M.I., Shahin, H.A., Khaleal, F.M.(2018): Mineralogical and geochemical characterization of radioactive minerals and rare earth elements in granitic pegmatites at G. El Fereyid, South Eastern Desert, Egypt. Journal of African Earth Sciences, 160, 1-14.

Sayyah, T.A., Assaf, H.S., Abdel Kader, Z.M., Mahdy, M.A. and Omar, S.A. (1993): New Nb_Ta occurrence in Gebel Ras baroud, Central Eastern Desert. Egyptian Mineralogist, 5, 41 .55.

Schürmann, H. M. E.(1966): The precambrian of the Gulf of Suez and the northern part of the Red Sea. E. J. Brill, Leiden. Netherland, $404 \mathrm{p}$.

Stern, R.J., 1979: Late Precambrian ensimatic volcanism in the Central Eastern Desert of Egypt, Ph.D. Thesis, Univ. Cal. San Diego., U.S.A. 
Comparason between Ras Baroud and Abu Hadeida Granites, Northern Eastern Desert, Egypt. To Determine the More Evolved One

Surour, A, A.Omar, S.A. and Zunic, T.B.(2004): Cation ordering and chemistry of cryptically zoned columbite from Ras Baroud rare-metal pegmatites, Central Eastern Desert, Egypt.6th International Conference On Geochemistry, Alexandria University, Egypt, pp777.795.

Taylor, S. R. and McLennan S. M.(1985): The continental crust; its composition and evolution. Blackwell, Oxford.

Zalata, A., Mashaal, S.H., Ghobrial, G., El.Tokhi, M. and Makroom, F.(1996): Mineral chemistry and geochemical studies on Wadi. Al-Barud, Wadi Umm Taghir, Pan-African dyke swarms, Eastern Desert, Egypt. Egyptian Mineralogist, 8, pp77-91.

Citation: Mohamed Abd El Monsif, (2020)" Comparason between Ras Baroud and Abu Hadeida Granites, Northern Eastern Desert, Egypt. To Determine the More Evolved One”, International Journal of Mining Science (IJMS), 6(3), pp. 30-45. DOI: http://doi.org/10.20431/24549460.0603004

Copyright: () 2020 Mohamed Abd El Monsif, This is an open-access article distributed under the terms of the Creative Commons Attribution License, which permits unrestricted use, distribution, and reproduction in any medium, provided the original author and source are credited. 